\title{
Correction: Activity-Based Proteomic Profiling of Deubiquitinating Enzymes in Salmonella- Infected Macrophages Leads to Identification of Putative Function of UCH-L5 in Inflammasome Regulation
}

\author{
Evangel Kummari, Navatha Alugubelly, Chuan-Yu Hsu, Brittany Dong, Bindu Nanduri, \\ Mariola J. Edelmann
}

The following information is missing from the Funding section: This study was supported by a Biotechnology Risk Assessment Grant Program competitive grant No. 2015-67016-22939 from the National Institute of Food and Agriculture and Agricultural Research Service.

\section{Reference}

1. Kummari E, Alugubelly N, Hsu C-Y, Dong B, Nanduri B, Edelmann MJ (2015) Activity-Based Proteomic Profiling of Deubiquitinating Enzymes in Salmonella-Infected Macrophages Leads to Identification of Putative Function of UCH-L5 in Inflammasome Regulation. PLoS ONE 10(8): e0135531. doi:10.1371/ journal.pone.0135531 PMID: 26267804

\section{f open ACCEss}

Citation: Kummari E, Alugubelly N, Hsu C-Y, Dong B, Nanduri B, Edelmann MJ (2015) Correction: Activity-Based Proteomic Profiling of Deubiquitinating Enzymes in Salmonella-Infected Macrophages Leads to Identification of Putative Function of UCH-L5 in Inflammasome Regulation. PLOS ONE 10(9): e0138635. doi:10.1371/journal.pone.0138635

Published: September 15, 2015

Copyright: @ 2015 Kummari et al. This is an open access article distributed under the terms of the Creative Commons Attribution License, which permits unrestricted use, distribution, and reproduction in any medium, provided the original author and source are credited. 